\title{
Budapest 1998
}

\author{
By Ron Holloway \\ Spring 1999 Issue of KINEMA
}

\section{9th HUNGARIAN FILM WEEK IN BUDAPEST}

Hungarian cinema, once the shining star in the socialist film firmament, is facing a production crisis. Only nine films programmed at the 29th Hungarian Film Week in Budapest (6-10 February 1998) were shot in $35 \mathrm{~mm}$, in contrast to the usual twenty of a decade ago. One sympathizes especially with the talented filmmakers of the past whose productions were eagerly viewed at all the international film festivals. Today, with only $\$ 2.5$ million available for projects at the Motion Picture Foundation of Hungary, co-production partners are the rule rather than the exception.

Nevertheless, as proven by sold-out performances for circa 100 festival entries-- features, shorts, documentaries, animation and experimental films, half of which produced on Beta SP video -- at the Corvin Multiplex in the commercial center of the city, a thirst for national film fare is clearly evident. Furthermore, the national share of the home box office is steadily increasing in relation to the growth of multiplexes, where an extra screen is nearly always set aside for an Hungarian film.

One entry hinted that the production crisis may be an illusion after all. For Bence Gyöngyössy's Romani Kris -- Gypsy Law, a debut feature by the son of the late Imre Gyöngyössy, the director returned to the same idyllic landscape location used by his father to shoot The Legend of the Death and Resurrection of Two Men (1972). Programmed at the Montreal World Film Festival, where it was awarded the Prix de Montreal for Best Debut Film, Romani Kris adapts motifs from Shakespeare's King Lear to tell the story of a Gypsy patriarch who expels his youngest daughter from the village for refusing to honor his birthday as requested, only to journey across the country later in search of her and to beg her forgiveness. A film that can effectively cross borders while still retaining its national character, Romani Kris was backed by two German TV stations (BR München and WDR Köln), Eurimages, and production companies in Hungary and Bulgaria.

Both the Hungarian Jury Prize and the Gene Moskowitz Critics Prize were awarded to György Feher's Passion, yet another adaptation of James M. Cain's novel The Postman Always Rings Twice that had inspired Luchino Visconti's neorealist Ossessione (Italy, 1942) as well as two Hollywood classics by Tay Garnett (1946) and Bob Rafelson (1980). The Hungarian version of this forbidden love-and-murder tryst leans heavily on experimental techniques -- handheld camera, long takes, static monologues in close-up, blackand-white images-- to cloak the story a depressing, claustrophobic, atmospheric state-of-mind. Should Feher be addressing current social conditions in his country, then his prognosis for the future is dreary indeed!

The most discussed film at Budapest was veteran director Karoly Makk's interpretation of the inspiration for Dostoyevsky's The Gambler, the festival's opening night presentation. Shot in English with exteriors in Baden-Baden, it starred British stage actor Michael Gambon in a splendidly mounted production that nevertheless reminded this viewer more of a Charles Dickens serial than a seminal masterpiece by the Russian author. Another entry in which "nationality" played a role was Tamas Toth's Natasha, filmed in Russia at the student-residence of Lomonosov University. One absurd scene follows another: a pet lynx runs through the corridors, voodoo ritual mixes with Balkan Gypsy music at a wedding celebration, a girl from Siberia heals wounds with magical powers, and on the fringe of this "tower of Babel" carnival lurks the sinister specter of a drug mafia. Although the real-location set intrigues as decorative backdrop, one expected more from the talented director who gave us Children of the Iron Gods (1993), his diploma feature film at the Moscow Film School (VGIK).

\section{References}

\section{AWARDS}




\section{Feature Films}

Main Prize: Szenvedély (Passion), directed by György Fehér.

Best Director: György Fehér, for Szenvedély (Passion).

Best Actress: Ildikó Bánsági, in Szenvedély (Passion).

Best Actor: Djoko Rossich, in Romani Kris-- Cigánytörvény (Romani Kris-- Gypsy Law); and Janos Derzi, in Szenvedély (Passion).

Best Debut Film: Presszó (Espresso), directed by Tamás Sas.

Best Cinematography: Miklós Gurbán, for Szenvedély (Passion).

Best Screenplay: Gábor Német, Tamás Sas, for Presszó (Espresso).

Best Experimental Film: Altamira, directed by Attila Mispál.

Best Short Film: Benda színész eltünése (Actor Benda Disappears), directed by Kata Nagy.

Special Jury Prizes: Tükrözödések (Reflections), directed by István Dárday and Györgyi Szalai); and Országalma (Orb), directed by György Czabán and György Pálos.

\section{Awards for Non-Fiction Films}

Main Prize: Tehetetlenül (Helpless), directed by Tamás Almási.

Category Prizes: Városlakók (City People), directed by András Salamon; and Megyek a TB-be (I Am Going to the Health-Care Office), directed by Gábor Ferenczi and Ágnes Sós.

Special Jury Prize: Szakitópróba (Tensile Test), directed by Ágota Varga.

\section{Gene Moskovitz Critics Award}

Szenvedély (Passion), directed by György Fehér.

\section{Author Information}

Ron HOLLOWAY (1933-2009) was an American critic, film historian, filmmaker and correspondent who adopted Europe as his home in the early fifties and spent much of his life in Berlin. He was an expert on the study of German cinema and against all odds produced, with his wife Dorothea, the journal German Film, keeping us up-to-date with the work of directors, producers and writers and the showing of German films around the world.

In 2007, Ron Holloway and his wife were awarded the Berlinale Camera Award. Ron also received the Bundesverdienstkreuz (German Cross of Merit), Polish Rings, Cannes Gold Medaille, the American Cinema Foundation Award, the Diploma for Support of Russian Cinema and an honorary award from the German Film Critics' Association.

Ron was also a valued contributor to Kinema for the past fifteen years. 